\title{
НЕСТАНДАРТНІ ФОРМИ РОЗВИТКУ КОМУНІКАТИВНОЇ КОМПЕТЕНТНОСТІ УЧНІВ ПОЧАТКОВИХ КЛАСІВ НУШ
}

Анотація. У статті досліджено теоретичні та практичні аспекти формування комунікативної компетентності молодших школярів НУШ. Вказано на фактори, що зумовлюють комунікативну активність. Розглянуто формування даної компетентності через цікаві для молодших школярів інтерактивні форми навчально-пізнавальної діяльності. Досліджено ефективність використання новітніх форм діяльності у поєднанні їх з іншими в процесі фрормування комунікативної компетентності. Доведено, що такі фрорми роботи під час навчання впливають на покращення мотивації молодших здобувачів освіти, покращують комунікативні навички та психологічну атмосферу у класі. Зазначено, що спілкування учнів під час навчально-виховного процесу е важливою умовою формування таких психічних якостей, як мислення, мовлення, уява, увага.

Ключові слова: особливості, методи, засоби, комунікативна компетенція.

Chos Svitlana Novoguyvin gymnasium

\section{NON-STANDARD FORMS OF DEVELOPMENT OF COMMUNICATIVE COMPETENCE OF STUDENTS OF PRIMARY CLASSES OF NUS}

Summary. Communicative competence is the knowledge of complex communication skills, cultural norms and limitations in communication, understanding of customs, traditions and etiquette in the field of communication and compliance with the rules of decency and politeness. In other words, it is a common feature of a kind of cultural personality, which includes communication skills, knowledge, skills and abilities, feelings and social experience in the fields of business, science, profession and everyday communication. Communicative competence is not created from the air, but gradually formed. The basis of its formation is the experience of human communication. In today's social situation, it is especially important to teach students oral and written communication. Therefore, at the initial level, the main task of teachers is to educate a fully developed, educated and sociable personality. Teaching children to speak correctly, accurately and beautifully is a difficult task that requires a comprehensive approach. The quality of further education and upbringing of junior schoolchildren largely depends on the success of its solution. The article investigates the theoretical and practical aspects of the formation of communicative competence of junior students of NUS. The factors that determine the communicative activity are indicated. The development of this ability is considered with the help of interesting interactive learning and cognitive activities for younger students. The efficiency of combining the latest forms of activity in the process of formation of communicative competence is studied. Practice has shown that this form of work during the school period affects the improvement of learning enthusiasm of junior students, improving communication skills in the classroom and the psychological atmosphere. It is seen that the communication of students in the learning process is an important condition for the formation of many mental qualities.

Keywords: features, methods, means, communicative competence.

\{омунікативна компетентність - це воло亿діння складними комунікативними навичками, знання культурних норм і обмежень в спілкуванні, усвідомлення звичаїв, традицій, етикету у сорері спілкування, дотримання правил пристойності та вихованість. Іншими словами - це сумарна властивість культурної особистості, що містить комунікативні здібності, знання, вміння і навички, чуттевий і соціальний досвід у сфрері ділового, наукового, професійного, побутового спілкування [5].

Постановка проблеми. Комунікативна компетентність не виникає на порожньому місці, вона фрормуеться поступово. Основою їі фрормування є досвід людського спілкування. Навчання школярів усному та письмовому спілкуванню має особливе значення у сучасній ситуації розвитку суспільства, тому вже в початковій школі основним завданням вчителя стає виховання всебічно розвиненої, освіченої та комунікативно-компетентної особистості. Навчити дітей правильно, влучно та красиво висловлюватись - складна задача, яка потребує комплексного підходу. Від успішності їі вирішення багато в чому залежить якість подальшого навчання і виховання молодших школярів [2].

Аналіз останніх досліджень і публікацій. 3 давніх часів шанувалися стислість і простота викладу думки. У Стародавній Греції величезне значення мала наука красномовства - риторика. Зараз цим питанням займаються багато наук, що вивчають діяльність людини: педагогіка, методика, фрілологія, психологія.

Теоретичні питання розвитку мовлення відбиваються в роботах видатних лінгвістів, методистів і вчителів-практиків - це К. Д. Ушинський, О. О. Леонтьєв, В. В. Акуленко, Л. В. Занков, Р. С. Нємов, Л. С. Виготський, К. М. Тищенко та інші.

Концепція загальної середньої освіти зазначає, що «освітніми результатами початкової школи $є$ повноцінні мовленневі, читацькі уміння і навички...». Тому комунікативні уміння та навички є першочерговими серед інших. Проаналізувавши наукові праці переконана, що роботу 
3 розвитку мовлення треба починати 3 перших днів перебування, учнів у школі.

Виділення не вирішених раніше частин загальної проблеми. Незважаючи на те, що проблема формування комунікативної компетентності в учнів НУШ не є новою та вже досить досліджена та висвітлена в багатьох науково-методичних розробках та в педагогічній пресі, окремі аспекти потребують доопрацювання та аналізу. Адже, сьогоднішні сучасні учні, діти покоління «Альфа», що мають кліпове мислення, легко переключаються та не можуть довго затримувати увагу на чомусь одному, потребують зовсім нових інтерактивних форм роботи, які їх зацікавлять та створять позитивну емоційну сореру уроку.

Мета статті. Описати особливості, методи, засоби та етапи формування комунікативної компетенції в учнів початкової школи в процесі навчання.

Виклад основного матеріалу. Комунікативна компетентність, згідно 3 психолого-педагогічними дослідженнями, містить наступні компоненти:

1. Емоційний (поєднує емоційну чуйність, емпатію, чутливість до іншого, здатність до співпереживання та співчуття, увагу до дій партнерів).2. Когнітивний (пов'язаний із пізнанням іншої людини, здатністю передбачати поведінку іншої людини, едективно розв'язувати різні проблеми, що виникають між людьми).

3. Поведінковий (показує здатність дитини до співпраці, спільної діяльності, ініціативність, адекватність у спілкуванні, організаторські здібності тощо) [4].

Одним із принщипових завдань педагога при дормуванні комунікативної компетентності є організація таких умов, при яких учні набувають навичок та умінь, що відповідають високому рівню спілкування.

Здатність до повноцінного спілкування охоплює:

- бажання вступати в контакт 3 навколишніми;

- здатність організувати спілкування, що передбачає вміння слухати співрозмовника, емоційно співпереживати, проявляти емпатію, вирішувати конфліктні ситуації;

- знання норм і правил, яких необхідно дотримуватися при спілкуванні.

Початок навчання в школі дозволяе дитині зайняти нову життеву позицію і перейти до виконання суспільно значущої навчальної діяльності. Тоді ж у більшості дітей молодшого шкільного віку складаються передумови формування важливих соціальних якостей, що сприяють успішній соціальній адаптації.

Вимоги до мовлення учнів. Яку ж мову можна вважати гарною, до чого слід прагнути вчителю та учням? До мовлення молодших школярів потрібно застосовувати наступні вимоги.

- Перша вимога - злістовність ловлення: говорити чи писати можна лише про те, що сам добре знаєш.

- Друга вимога - логічність, послідовність, чіткість побудови мовлення.

- Tочність - це третя вимога мовлення, яку розуміють як уміння не просто передати факти, спостереження, почуття відповідно до ситуащії, але і вибрати для ціеї мети найкращі мовні засоби.
- Мова лише тоді впливає на читача і слухача 3 потрібною силою, коли вона виразна. Виразнicmb мовлення - це вміння яскраво, переконливо, стисло передати думку, це здатність впливати на людей інтонаціями, добором фрактів, побудовою фрази, підбором слів.

- Зрозулілість мовлення - це доступність сприйняття мовлення тими людьми, до кого воно звернене.

- Надзвичайно важливими є також гарна дикція, чітке вимовляння звуків, дотримання правил орфоепії, вміння говорити й читати виразно, вміло володіти інтонаціями, паузами, логічними наголосами тощо.

Для школи особливо велике значення має правильність, тобто відповідність мовлення до прийнятих у суспільстві літературних норм [1].

Таким чином, говорити про хороше мовлення можна лише в тому випадку, якщо:

- воно багате та насичене різноманітними лексичними й граматичними засобами;

- в ньому точно передано зміст висловлювання;

- враховані особливості ситуації спілкування.

Володіння комунікативними вміннями на високому рівні дозволяє ефективно взаємодіяти з іншими людьми при різних видах діяльності. Важливо почати формування комунікативних умінь саме в молодшому шкільному віці для поетапного розвитку надалі. Активізація комунікативної діяльності молодших школярів передбачає процес спонукання учнів до енергійного, цілеспрямованого спілкування. Спілкування - невіддільна частина будь-якого уроку, тому формування комунікативних умінь учнів веде до підвищення якості навчально-виховного процесу.

Комунікативний розвиток йде різними шляхами. Це кількісне накопичення (збільшення словникового запасу, обсягу висловлювання) i якісні зміни (вимова, розвиток зв'язного мовлення, розуміння зверненої до вас мови). Однак основним критерієм інтенсивності та успішності форомування комунікативної особистості є вміння розуміти, ставити та вирішувати різні за характером комунікативні завдання, тобто вміння правильно й оптимально використовувати свою мовленнєво-мисленнєву діяльність у спілкуванні з іншими людьми, засобами інформації та з самим собою.

$\mathrm{У}$ роботі над розвитком комунікативних здібностей варто використовувати:

- методику навчання діалогічного мовлення.

- методику навчання монологічного мовлення.

- комплексне навчання видам мовленневої діяльності.

- методику роботи з розвитку зв'язного усного та писемного мовлення в початковій школі.

Уведення комплексу спеціальних вправ чи ситуацій в навчальний предмет читання сприяє отриманню стійких позитивних результатів. Найкращим джерелом поповнення словника школярів, безсумнівно, $є$ література, класичні зразки, мова інтелігентних людей, вчителів в першу чергу. Не менш важливе очищення мови школярів від ненормативної лексики, діалектизмів, жаргонізмів [1].

Ситуащіі, створювані на уроках літературного читання, мають спрямовуватися на те, щоб дитина пропустила через себе вчинки, скоєні літератур- 
ним героєм, вчилася б вірити, товаришувати, поважати, любити, аналізувати різні життеві ситуації. Такий підхід забезпечуе розвиток мовлення учня, вчить вступати в діалогічні суперечки про перевтілення літературних героїв, дає прекрасну можливість розвитку монологічного мовлення.

Для створення емоційно-сприятливої ситуації на уроці необхідно використовувати:

1) завдання, спрямовані на розвиток літературних здібностей і творчої уяви:

- розповідь від першої особи (розповісти від імені Лисички про те, як вона пригощала Журавля)

- розповідь від імені предмета, наприклад, глечика, з якого їла Лисичка в гостях у Журавля (Що думав, що спостерігав зі сторони? Що чув та відчував? Що хотів би зробити тощо);

2) ігрові прийоми (участь дітей в іграх і вправах сприяе виникненню між дітьми доброзичливих відносин, а групова підтримка викликає почуття захищеності, що дозволяе навіть боязким чи тривожним дітям долати страх спілкування);

3) комплімент

- комплімент казковому чи літературному герою (похвала за вчинок, гарний вигляд);

4) вправа «Юний автор»

- включення в назву казки нового об'єкта, наприклад «Колобок та чарівна паличка»;

- складання нової казки за новою назвою;

5) Вправа «Відділ кадрів»

- діти проводять уявну співбесіду, беручи на «роботу» до твору (або відмовляючи) якогось казкового, вигаданого чи реального персонажа (Чи маєте досвід роботи? В якому творі працювали? Як можете вплинути на сюжет чи кінцівку твору? і под.);

4. Вправа «Зміни казкову розв'язку»

- придумати інше закінчення казки, оповідання (смішне, цікаве, сумне, франтастичне) [6].

Навчальне кооперування як засіб розвитку мовлення школярів. Робота в парах і групах допомагає організації спілкування, тому що кожна дитина має можливість говорити з зацікавленим співрозмовником. Одна 3 головних умов організації діалогу - це створення атмосфери довіри й доброзичливості, свободи та взаєморозуміння, співтворчості рівних і різних. Вибудовуючи відносини, можна виділити деякі правила ведення діалогу:

- важлива будь-яка думка;

- хочеш говорити - підійми руку;

- ти маєш право на будь-яку реакцію, крім неуваги чи неповаги;

- звернення починається з імені;

- сиди так, щоб бачити обличчя мовця,

- дай можливість іншій людині висловити свою думку, а собі - зрозуміти їі;

- відсутність результату - теж результат;

- зауваження чи критика мають бути тактовними;

- голос - твій природний дар, вмій (учись) ним володіти.

Для організащії діалогу з автором художнього твору необхідна організація читацької діяльності, яка містить наступні компоненти:

- емоційне вслуховування;

- вчитування;

- виразне читання;

- твори, малювання, інсценування.
Творчі ігри, окрім виховання і навчання учнів, сприяють також формуванню комунікативних умінь та дають дітям можливість пережити й відчути зворушливі, яскраві події в уявних умовах. Гра - «це не тільки показ, переживання вчинку, це ще й думка - дія, і думка - образ». I в цьому їі виховна та дидактична сила.

Таким чином, діалог, живе спілкування, тренінги, мовленнева комунікація є тим фрундаментом, на якому будуть рости й розвиватися школярі. Тренування в спілкуванні на навчальному занятті дає учневі можливість не тільки підвищити свої навчальні досягнення, але і вплинути на майбутній профресійний вибір.

Основну роль в початковій школі відіграють групові заняття, заходи, ігри. Саме вони допомагають учням адаптуватися в суспільстві та відчувати себе частиною соціального середовища. Дані заняття покращують комунікативні компетенції молодших школярів, роблять їх розкутими та товариськими.

Комунікативна компетенція молодших школярів ефективно формується в спеціально організованій груповій роботі на основі кооперації. Кооперативним методам навчання останнім часом в початковій школі приділяеться велика увага. Важливість кооперації з однолітками розкривається у вітчизняних дослідженнях (В. Дьяченко, Г.А. Цукерман та ін.). Згідно 3 дослідженнями психологів, процес навчання набуває соціально-комунікативного характеру, а шкільний клас розглядається як певна комунікативна система. Отже, залучення учнів до навчального кооперування сприятиме формуванню їх комунікативної компетенції.

Навчальна кооперація виступає як змістовна та продуктивна міжособистісна взаємодія школярів, що забезпечує фрормування соціальних якостей особистості шляхом збагачення кожного при одночасному поділі між ними фрункцій, ролей і обов'язків; рефлексію процесу і результату міжособистісної взаємодії; використання знань педагога як одного з джерел інформації [8].

«Навчальна кооперація» як поняття наближене до поняття «співпраця». Ми розглянемо кілька варіантів організації навчання у співпраці на основі малих груп в початковій школі.

Навчання в малих груnax Student Teams Achievement Division (STAD) можна використовувати на будь-якому уроці. Група, як правило, складається 34 осіб різного рівня підготовленості. Типова структура уроку виглядає так:

1. Актуалізація знань.

2. Вивчення нової теми й пояснення вчителя.

3. Індивідуальне відпрацювання учнями отриманих навичок.

4. Робота в групах: загальне й однакове для всіх груп завдання виконуеться коментовано.

5. Індивідуальна перевірка досягнутого на основі тестування, опитування.

6. Оцінювання членів групи, при якому всі учасники однієї групи отримують одну оцінку.

Навчання у співпраці читанню та складання mвopis y Cooperative Integrated Reading and Composition (CIRC). Робота може бути організована по-різному:

1. Учні з 4 осіб розбиваються на пари. Одна пара самостійно читає один одному текст, скла- 
дають план переказу, розповідають чи обговорюють прочитане один одному, виділяючи головні думки, пишуть відповіді на питання по тексту, працюють зі словником, з іншою парою працюе педагог.

2. Якщо клас не ділиться на однорідні групи, то всі учні у всіх групах працюють спільно, намагаючись визначити головну ідею тексту і зрозуміти загальний зміст оповідання при відповідях на проблемні питання до тексту. Усі працюють єдиною командою. Вся діяльність в групах здійснюється під контролем вчителя. Тести даються учням тільки тоді, коли вчитель переконуеться, що вони готові до них.

Прийом «Пилка» (Jigsaw) застосовуеться тоді, коли навчальний матеріал можна розбити на фррагменти. Найважливіше, що кількість таких фрагментів має збігатися з кількістю учасників групи. Це можуть бути тестування за картками, усні відповіді на запитання вчителя, адресовані будь-якому члену групи за вибором педагога, або спільну доповідь, підготовлений групою. Основний аспект - група отримуе одну оцінку на всіх. У початковій школі цей метод найбільш вдало використовуеться на уроках ЯДС, образотворчого мистецтва, природознавства, літературного читання (при узагальнюючому повторенні) [7].

Запропоновані варіанти організації навчання у співпраці сприяють ефрективному формуванню комунікативної компетенції молодших школярів: стимулюють бажання учнів розширити свої знання 3 предмету, що вивчається; розвивають інтерес до творчої роботи, досліднищькі здібності; формують уміння роботи в групі, сприяють подоланню невпевненості в своїх навчальних уміннях і силах; створюють умови для комфортного перебування кожного учня будь-якої творчої групи.

Успіх в опануванні мови - це запорука успіху в шкільному навчанні та загальному розвитку взагалі. Саме через мову, через мовлення перед школярами відкривається широкий світ науки і життя. Для досягнення успіхів у цій справі необхідна систематична та кропітка робота.

Висновки. Існуючі методи і прийоми розвитку мовленнєвої діяльності поєднуються в роботі учнів і вчителя, доповнюють один одного і в сукупності створюють базу для системи розвитку мовленневої діяльності учнів початкової школи.

Досконале опанування комунікативних здібностей - ключ до пізнання, освіченості, розумового розвитку, повноцінної участі у суспільному житті кожної людини.

Розвиток комунікативних здібностей молодших школярів потрібно здійснювати на всіх уроках і позаурочний час, виконуючи певні вправи з розвитку зв'язного мовлення, які активізуватимуть розумові здібності учнів та допомагатимуть кожному учневі проявити свої потенційні можливості.

\section{Список літератури:}

1. Види вправ з розвитку мовлення молодших школярів на уроках читання. URL: http://www.startpedahohika.com/ sotems-1127-6.html

2. Жинкін М.I. Мова як провідник інформації. Москва : Наука, 1982. 160 с.

3. Земцова Е.А. Гимнастика для речи. Начальная школа. 2011. № 2. С. 29-32.

4. Климова К.Я. Комунікативні ознаки мовлення. Основи культури і техніки мовлення. Київ : Ліра, 2004. С. 7.

5. Новак М.В. Теоретичні основи формування комунікативної компетентності молодших школярів. Початкова школа. 2014. № 2. С. 56-58.

6. Погорелова Т.В. Формування комунікативної компетентності першокласників. Початкове навчання та виховання. 2018. № 13-15. С. 44-50.

7. Пометун О.І., Пироженко Л.В. Сучасний урок. Інтерактивні технології навчання : Наук. метод. посіб. Київ : Видавництво А.С.К., 2004. 192 с.

8. Щербань С., Коротун I. Інтерактивні техніки і технології групової роботи на уроках. Початкова освіта. 2007. № 4.

\section{References:}

1. Vydy vprav z rozvytku movlennia molodshykh shkoliariv na urokakh chytannia [Types of exercises for speech development of junior schoolchildren in reading lessons]. Available at: http://www.startpedahohika.com/ sotems-1127-6.html

2. Zhynkin M.I. (1982) Mova yak providnyk informatsii [Language as a conductor of information]. Moscow: Nauka, $160 \mathrm{p}$.

3. Zemtsova E.A. (2011) Hymnastyka dlia rechy [Gymnastics for speech]. Nachalnaia shkola, vol. 2, pp. 29-32.

4. Klymova K.Ya. (2004) Komunikatyvni oznaky movlennia [Communicative signs of speech]. Osnovy kultury $i$ tekhniky movlennia. Kyiv: Lira, vol. 7.

5. Novak M.V. (2014) Teoretychni osnovy formuvannia komunikatyvnoi kompetentnosti molodshykh shkoliariv [Theoretical bases of formation of communicative competence of junior schoolchildren]. Pochatkova shkola, vol. 2 , pp. 56-58.

6. Pohorielova T.V. (2018) Formuvannia komunikatyvnoi kompetentnosti pershoklasnykiv [Formation of communicative competence of first-graders]. Pochatkove navchannia ta vykhovannia, vol. 13-15, pp. 44-50.

7. Pometun O.I., Pyrozhenko L.V. (2004) Suchasnyi urok. Interaktyvni tekhnolohii navchannia: Nauk. metod. posib. [Interactive learning technologies]. Kyiv: Vydavnytstvo A.S.K., $192 \mathrm{p}$.

8. Shcherban S., Korotun I. (2007) Interaktyvni tekhniky i tekhnolohii hrupovoi roboty na urokakh [Interactive techniques and technologies of group work in lessons]. Pochatkova osvita, vol. 4. 